\title{
RANCANG BANGUN DASHBOARD ADMINISTRASI AKADEMIK DI SMK FADILAH TANGERANG SELATAN
}

\author{
Sofa Sofiana \\ Teknik Informatika, Fakultas Teknik, Universitas Pamulang \\ Email: sofiana82@gmail.com
}

\begin{abstract}
ABSTRAK
Untuk meningkatkan proses bisnis organisasi, penerapan sistem administrasi akademik mutlak diperlukan. Dalam penelitian ini di kaji rancang bangun dashboard administrasi akademik sebagai solusi terhadap proses pengambilan keputusan pimpinan yang masih dilakukan manual, sehingga membantu efektifitas dalam mengelola SMK Fadilah Tangerang.Penelitian ini menggunakan metode penelitian eksperimental dengan metode rekayasa waterfall. Teknologi aplikasi berbasis web dengan pemograman MVC, PHP, highcharts sebagai visualisasi dashboard. Penelitian yang didapat adalah terciptanya aplikasi dashboard, dan kepuasan pimpinan terhadap rancangan aplikasi. Hasil kesimpulan menunjukan bahwa rancangan ini dapat diimplementasikan sebagai bentuk penerapan teknologi terkini sehingga mengoptimalkan pengambilan keputusan.
\end{abstract}

Kata kunci: dashboard, UML, MVC, pengambilan keputusan

\section{PENDAHULUAN}

Organisasi seringkali dihadapkan pada perubahan lingkungan bisnis yang semakin cepat. Organisasi perlu melakukan monitoring dan pengukuran secara terus - menerus untuk memastikan bahwa proses bisnis yang dijalankan dapat mencapai tujuan yang ditetapkan, melalui strategi pengelolaan yang tepat. Pengukuran kondisi organisasi memerlukan data dan informasi yang tepat dari seluruh bagian organisai.Informasi tersebut juga harus disampaikan kepada pihak yang tepat, pada waktu yang tepat pula.[1]

Kejadian diatas sama halnya dengan organisasi sekolah. Di tingkat pendidikan manapun, dimana persaingan antar institusi pendidikan juga semakin ketat, diperlukan sebuah mekanisme penyajian pelaporan secara sederhana, mudah di baca dan cepat sehingga dapat membatu pimpinan atau wakilnya dalam membuat sebuah analisa keputusan. Terlebih jika informasi tersebut akan disampaikan kepada pihak eksternal seperti pelaporan kedinasan, kerjasama dengan pihak lain sebagainya.[2]

SMK Fadilah sebagai institusi pendidikan juga mendapatkan kasus yang sama. Kepala Sekolah beserta jajarannya (Kepala Jurusan guru BP serta Wali Kelas ) sebagai pengambilan keputusan dalam proses kegiatan belajar mengajar, sulit mendapatkan data yang faktual, komprehensif serta ringkas terhadap pemantauan kinerja proses siswa dan guru.[3]
Salah satu metode penyelesaian masalah diatas adalah dengan membangun teknologi penyajian data dengan dashboard. Dasboard memberikan tampilan antarmuka dengan berbagai bentuk seperti diagram, laporan, indikator visual, mekanisme alert, yang dipadukan dengan informasi yang dinamis dan relevan. Tujuan dari rancang bangun dashboard tidak lain adalah untuk mengukur kinerja, memonitoring proses yag sedang berlangsung, dan memprediksi kondisi di masa yang akan datang.[4]

\section{Perumusan Masalah}

Berdasarkan paparan diatas, dapat dirumuskan pokok - pokok permasalahan sebagai berikut : Bagaimana aplikasi dashboard yang dapat membantu efektivitas Kepala Sekolah, Kepala Jurusan, Wali Kelas dan guru BP dalam mengelola sekolahnya, sehingga dapat membantu proses pengambilan keputusan yang cepat dan akurat?

\section{LANDASAN TEORI \\ Teori Dashboard}

Dashboard merupakan papan penunjuk instrumen [5]. Menurut Ejaan Bahasa Indonesia yang disempurnakan dashboard ditulis dengan dasbor, yang berarti papan penunjuk.[4]

Jika kita mengendarai mobil, informasi vital mengenai kecepatan, tekanan oli, temperatur, dan lainnya tersedia didepan kita dashboard lengkap dengan indikator bahan 
bakar, lampu warna merah dan hijau serta indikator kecepatan dengan jarum searah jarum jam. Dengan analogi yang sama, maka kini para manajer mengandalkan dashboard sebagai alat bantu untuk pengukuran kinerja bisnis. Ide dasar atau manfaat dari dashaboard sama dengan analogi kegunaan dashboard bagi pengemudi. [5] Adapun jenis dashboard dikelompokkan menjadi sebagai berikut :

1. Dashboard Strategis, untuk mendukung keselarasan ( alignment) organisasi dengan strategis organisasi.

2. Dashboard Taktis, yang mendukung pengukuran pencapaian hasil dari suatu proyek atau kebijakan.

3. Dashboard Operasional, yang mendukung pengendalian aktivitas bisnis tertentu. [6]

Gambaran Umum Dashboard dapat di lihat pada gambar 1

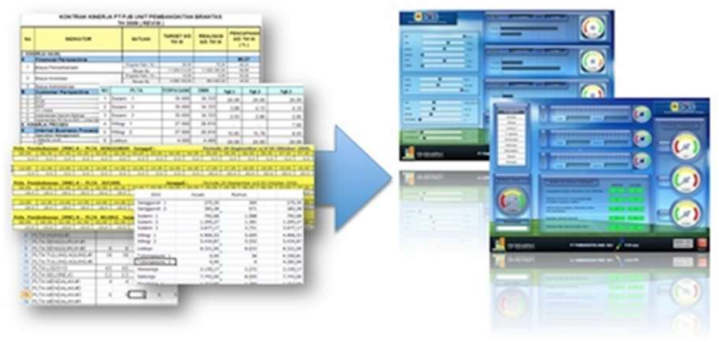

Gambar 1 Gambaran Umum Dashboard

\section{Teori Elicitation}

Elisitasi merupakan rancangan yang dibuat berdasarkan sistem baru yang diinginkan oleh pihak manajemen terkait dan disanggupi oleh penulis untuk dieksekusi. Elisitasi didapat melalui metode wawancara dan dilakukan melalui tiga tahap, yaitu :[7]

Elisitasi tahap I, berisi seluruh rancangan sistem baru yang diusulkan oleh pihak manajemen terkait melalui proses wawancara.Elisitasi tahap II, merupakan hasil pengklasifikasian elisitasi tahap I berdasarkan metode MDI. Metode MDI bertujuan memisahkan antara rancangan sistem yang penting dan harus ada pada sistem baru dengan rancangan yang disanggupi oleh penulis untuk dieksekusi. Elisitasi tahap III merupakan hasil penyusutan elisitasi tahap II dengan cara mengeliminasi semua requirement dengan option I pada metode MDI. Selanjutnya, semua requirement yang tersisa diklasifikasikan kembali melalui metode TOE ( Teknik, Operational dan Economic ).

\section{Teori Waterfall}

Siklus klasik/model air terjun rekayasa perangkat lunak SIM didasarkan siklus konvensional dalam bidang rekayasa lainnya dengan pendekatan yang sistematis. Tahapan tahapan dalam siklus klasik/model air terjun rekayasa perangkat lunak SIM adalah sebagai berikut :

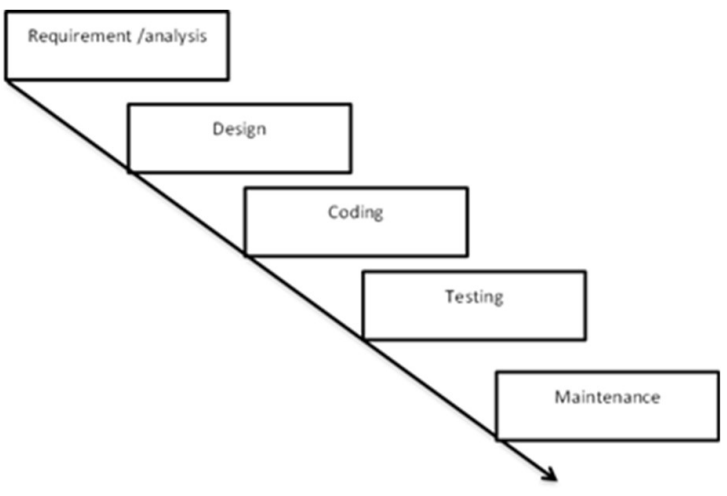

Gambar 2 Model Waterfall

\section{Teori MVC ( Modelling View Controller )}

Model, Model mewakili struktur data. Biasanya model berisi fungsi-fungsi yang membantu seseorang dalam pengelolaan basis data seperti memasukkan data ke basis data, pembaruan data dan lain-lain.

View, View adalah bagian yang mengatur tampilan ke pengguna. Bisa di katakan berupa halaman web.

Controller, Controller merupakan bagian yang menjembatani model dan view. Controller berisi perintah-perintah yang berfungsi untuk memproses suatu data dan mengirimkannya ke halaman web.

Dengan menggunakan metode MVC maka aplikasi akan lebih mudah untuk dirawat dan dikembangkan. Untuk memahami metode pengembangan aplikasi menggunakan MVC diperlukan pengetahuan tentang pemrograman berorientasi objek (Object Oriented Programming). Alur kerja dari MVC dapat di lihat pada gambar 3 


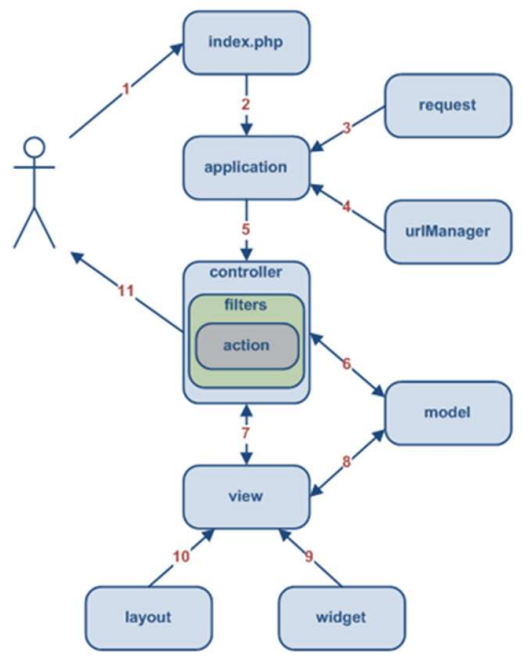

Gambar 3 Alur Kerja MVC

\section{METODE PENELITIAN}

Penelitian ini menggunakan metode penelitian eksperimental dengan metode waterfall. Dimana didalamnya terdapat metode Requirement Elicitation dan sebagainya.Adapun tahapan penelitian dapat dilihat pada gambar di bawah ini.

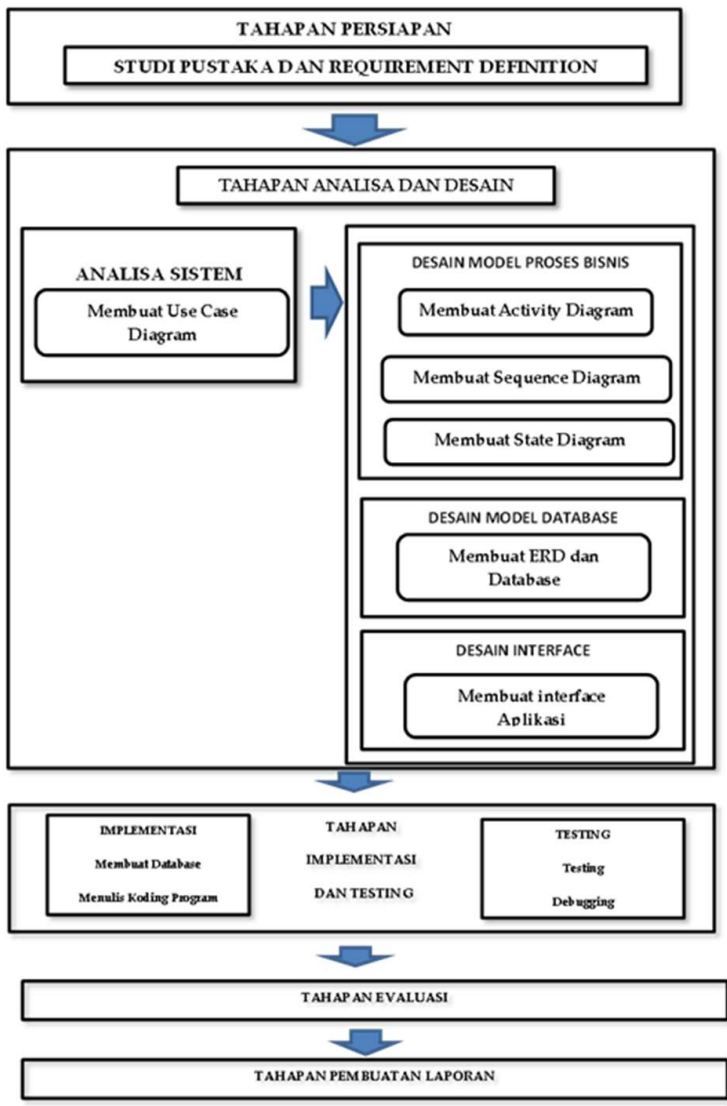

Gambar 4 Pengembangan Konsep Waterfall

\section{HASIL DAN PEMBAHASAN Tahap Elisitasi}

Setelah melakukan studi pustaka dan observasi dan wawancara terhadap stakeholder, maka didapat beberapa kebutuhan yang diperlukan guna membangun sebuah sistem yang diinginkan, kebutuhan-kebutuhan user dengan metode elisitasi. Adapun hasil elisitasi final adalah sebagai berikut :

1) Menampilkan versifikasi menu login

2) Menampilkan menu utama dashboard SMK Fadilah

3) Menampilkan header SMK Fadilah

4) Menampilkan menu logout

5) Menampilkan dashboard informasi absensi guru

6) Menampilkan dashboard informasi absensi siswa

7) Menampilkan dashboard pembayaran SPP

8) Menampilkan data realisasi penyelesaian RPP

9) Staff TU dapat menginput data master siswa, kelas, guru, mata pelajaran, SKKM dan menginput realisasi SPP siswa

10) Kepala Sekolah memiliki hak akses dashboard secara keseluruhan

11) Guru piket dapat menginput absensi siswa dan guru perhari

12) Tingkatan user dapat terbagi sesuai hak aksesnya

13) Tampilan sistem mudah digunakan dan dipahami oleh user

14) Tampilan sistem simple dan menarik

15) Memiliki keamanan data yang bagus

16) Tampilan memiliki ciri khas SMK Fadilah

17) Menampilkan sistem yang user friendly ( mudah dipahami user )

\section{Tahap Pemodelan Use Case Yang Berjalan}

Dari diagram use case di samping dapat dijelaskan bahwa terdapat 4 aktor utama, yaitu : guru piket, staff TU, Kepala jurusan, dan Kepala Sekolah. 4 aktor inilah yang menjalankan sistem yang berjalan diantaranya guru piket akan melakukan fungsional menginput absen guru dan absen siswa secara manual, staff TU akan melakukan fungsional menginput data realisasi KKM siswa, pelanggaran siswa dan pembayaran SPP, kepala jurusan akan menjalan fungsional menginput realiasi penyelesaian RPP, realisasi kelulusan Ujian Nasional siswa. Kepala sekolah 
akan melihat semua laporan yang dibuat oleh aktor lain secara manual.

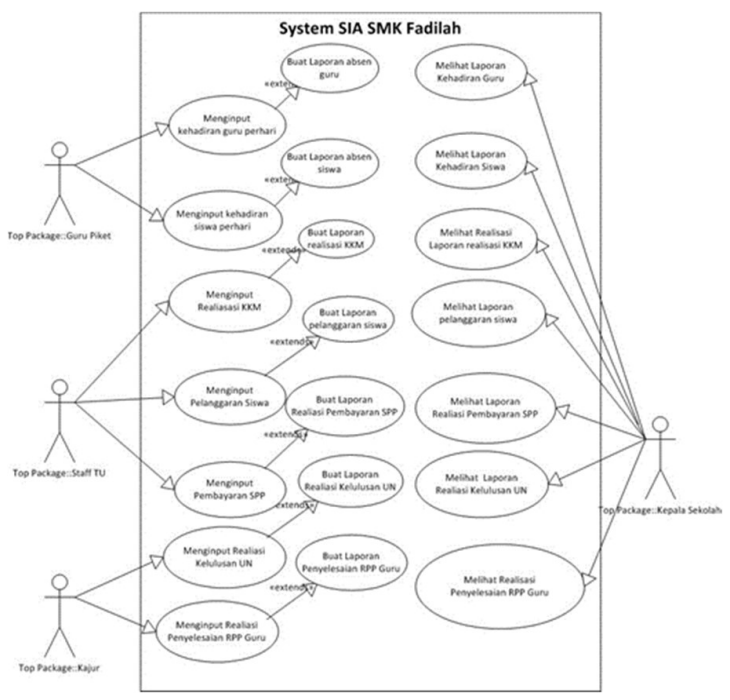

Gambar 4 Use Case yang berjalan

Tahap Pemodelan Use Case Package Yang Di usulkan

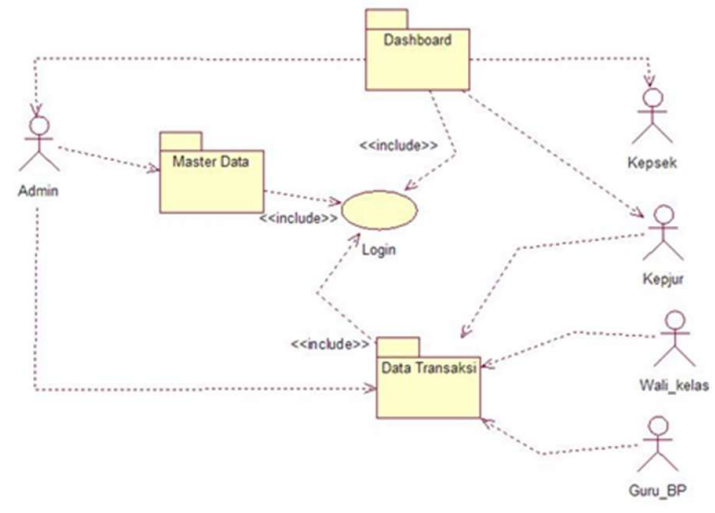

Gambar 5 Use Case Package yang di usulkan

Dari gambar di atas dapat di jelaskan bahwa terdapat 5 aktor yaitu Admin, Kepala sekolah ( Kepsek), Kepala Jurusan ( Kepjur ), Wali kelas serta Guru BP. Setiap aktor dalam mengakses sistem di haruskan log in terlebih dahulu. Admin dapat melakukan transaksi secara penuh kepada master data.Kepala sekolah hanya dapat melihat dashboard, tanpa dapat melakukan transaksi kepada master data. Kepjur, Wali Kelas dan guru BP dapat melakukan transaksi sesuai role-nya antara lain input realiasasi absen guru, input realiasasi absen siswa, input realisasi RPP guru, input realisasi pelanggaran siswa, input realisasi pembayaran SPP serta input realiasasi pencapaian

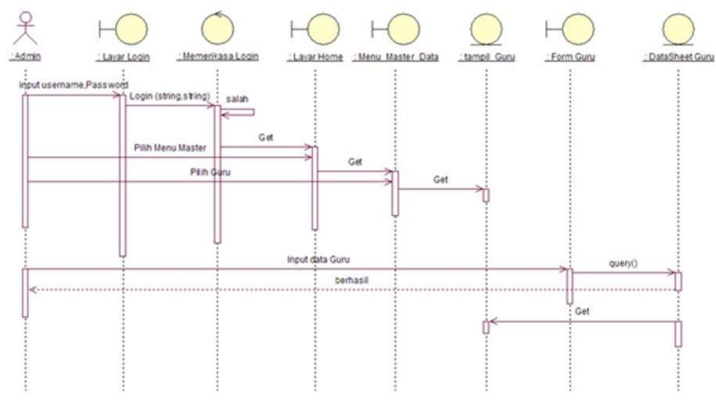

Gambar 6 Sequence Guru

Gambar diatas adalah sequence diagram transaksi guru pada master data : untuk masuk ke dalam sisyem admin harus log in terlebih dahulu, lalu system akan melakukan verifikasi. Jika berhasil, maka tampilan home akan tampil, admin memilih master data lalu memilih guru yang akan dilakukan transaksi pada form guru, dilanjutkan melakukan proses query dan menampilkannya kembali.

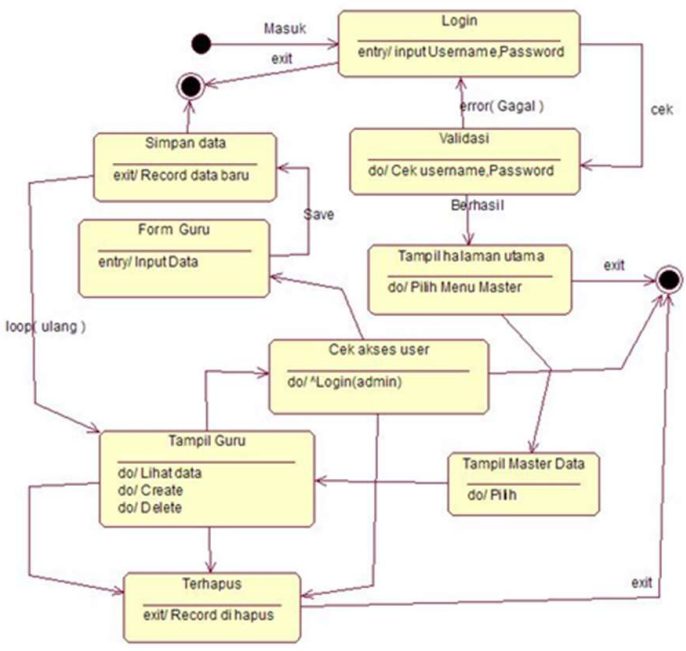

Gambar 7 State Diagram

Untuk menginput, edit atau tambah pada master data guru, maka user memasuki sistem dengan $\log$ in lalu dilakukan verifikasi, jika berhasil, maka akan tampil halaman utama dan memanggil master data. Dalam master data, user dapat melakukan transaksi sesuai role user. Admin dapat membuat record guru baru pada form guru lalu menyimpannya, dan menampilkannya kembali. 
Model Rancangan Basis Data

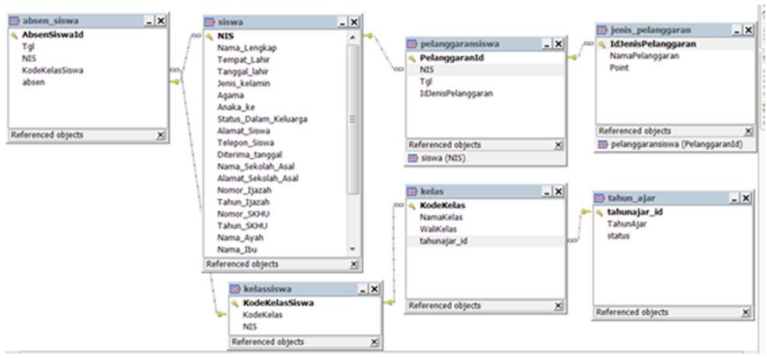

Gambar 8 Rancangan Basis data siswa

Dari rancangan basis data diatas dapat dijelaskan bahwa pada tabel siswa memiliki primary key NIS yang memiliki relationship dengan tabel - tabel lain dengan relasi foreign key.

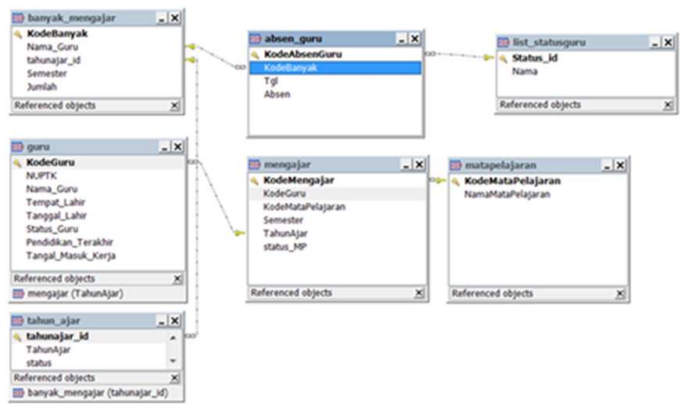

Gambar 9 Rancangan Basis Data Guru

Pada rancangan basis data diatas dapat dilihat bahwa yang menjadi tabel master adalah tabel guru dengan KodeGuru sebagai Primary Key-nya, lalu memiliki relationship dengan tabel - tabel lain dengan relasi foreign key.

\section{Rancang Bangun MVC}

1. Proses rancang bangun dapat dibuat Pembuatan site request index.php atau path pada rancang bangun dashboard ini adalah

C: \wamp\www $\backslash$ sofalindex.php.

Kemudian server Web menangani permintaan dengan menjalankan skrip bootstrap index. php.

2. Skrip bootstrap membuat sebuah instance Aplikasi dan menjalankannya.

3. Aplikasi mendapatkan rincian informasi permintaan pengguna dari komponen aplikasi bernama request. Pada tahap ini biasanya user menkonfigurasi dari CWebApplication
4. Aplikasi menentukan controller dan aksi yang diminta dengan bantuan komponen aplikasi bernama urlManager.

5. Aplikasi membuat instance controller yang diminta untuk selanjutnya menangani permintaan pengguna.

6. Aksi membaca Model yang dibuat.

7. Aksi menyiapkan View / tampilan bersama show dan model Post. [8]

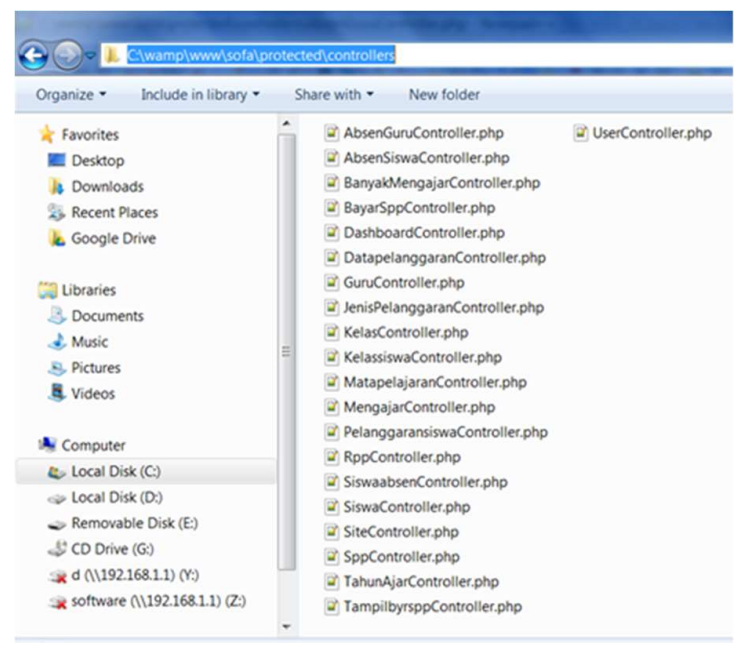

Gambar 10 List Controller pada MVC

\section{Implementasi Dashboard}

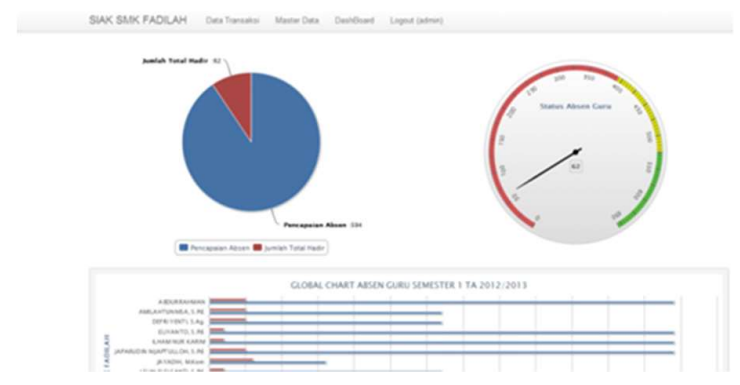

Gambar 10 Tampilan Implementasi Dashboard Absen Guru

Pada gambar diatas contoh impelemetasi realiasi pencapaian absen guru dimana disebelah kiri terdapat grafik pie yang menggambarkan pencapaian dan rasio dengan target hadir dalam satu semester. Target hadir dalam satu semester di tetapkan 594 kali dengan realisasi baru mencapai 62 kali.Di sebelah kanan terdapat gauge/speedometer yang juga terhubung dengan database. 


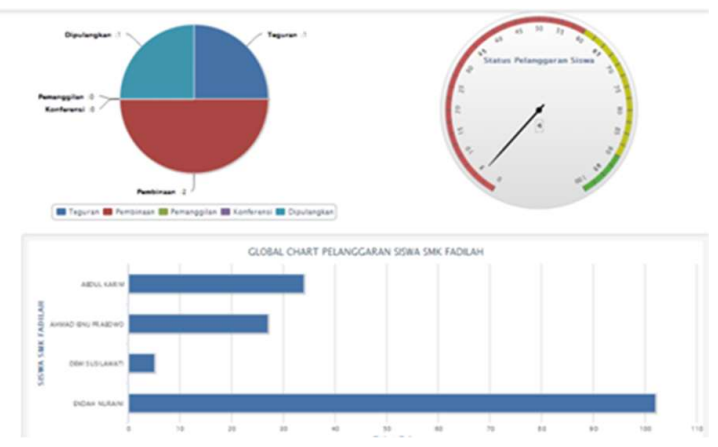

Gambar 11 Tampilan Implementasi Realisasi Pelanggaran Siswa

Gambar sebelah kiri diatas dapat dilihat bahwa terdapat 4 siswa yang mendapatkan pelanggaran.Terlihat 2 orang siswa mendapatkan pembinaan.Satu siswa di pulangkan dan satu orang siswa mendapatkan teguran. Disebelah kiri terdapat gauge yang menampilkan total jumlah siswa yang melanggar yaitu 4 siswa. Dbagian bawah terdapat grafik batang yang menggambarkan detail nama siswa yang melanggar beserta pointnya. Adapun ketentuan poin pelanggaran terdapat pada lampiran laporan ini.

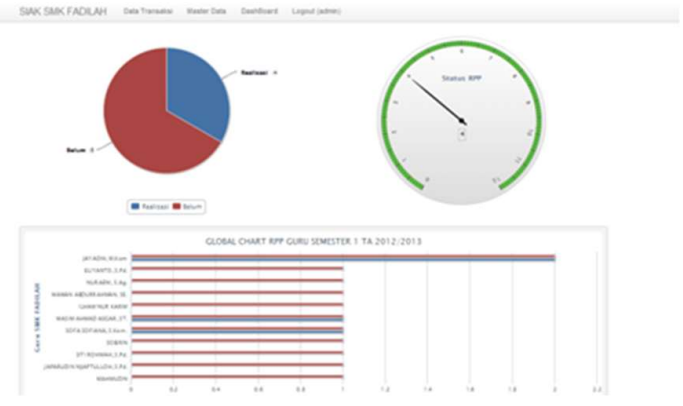

Gambar 12 : Tampilan Realisasi RPP Guru

Pada tampilan diatas sebelah kiri dapat digambarkan bahwa terdapat 8 RPP yang belum di selesaikan dan 4 yang sudah selesai. Disebelah bawah terdapat detail pencapaian penyelesaian RPP tiap guru, dimana perbandingan warna menggambarkan statusnya. Pada gauge sebelah kanan terlihat baru 4 RPP yag sudah diselesaikan oleh semua guru.

\section{KESIMPULAN}

Berdasarkan pada permasalahan yang muncul, kemudian dianalisa dan di buat desain serta diimplementasikan, maka dari rancang bangun aplikasi dashboard administrasi akademik di SMK Fadilah ini diambil beberapa kesimpulan sebagai berikut:

1. Rancang bangun dashboard administrasi akademik di SMK Fadilah dapat diterapkan untuk membantu Kepala sekolah, kepala jurusan, wali kelas dan guru BP dalam proses pengambilan keputusan.

2. Metode waterfall disertai rancang bangu dengan teknik MVC dan metode Requirement Elicitation dirasa mampu menjadi metode rancang bangun dashboard yang cukup singkat untuk implementasi proyek IT.

3. Implementasi dashboard juga secara tidak langsung akan meningkatkan prestasi tata kelola manajemen yang sudah berbasis IT, sehingga akan berdampak positif pada penilaian kepercayaan masyarakat akan SMK Fadilah.

\section{DAFTAR PUSTAKA}

[1] Alb. Ladjamudin, Analisa dan Desain Sistem Informasi. Jakarta: Graha Ilmu, 2015.

[2] "Peraturan Menteri Pendidikan Nasional No 20 Tahun 2007," Departemen Pendidikan Nasional, Indonesia, 2007.

[3] "Buku Panduan Akademik." SMk Fadilah, Tangerang Selatan, 2011.

[4] B. M. Prasetio, "Perancangan Dashboard Information System pada Penerimaan Mahasiswa Baru di Perguruan Tinggi Raharja," STMIK Raharja, 2013.

[5] M. H. Henderi,. Rahardja, Untung.,Qory,Oktisa, . "“'Dashboarding InformationSystemsFor The EducationSector: Applicationand Methodologies," CCIT STMIK Raharja, vol. 5, no. 1, 2011.

[6] M. B. Rasmussen, Nills, Claire Y Chen, Bussiness Dashboard. Jakarta: Penerbit PPM, 2010.

[7] R. Amalia, "Penerapan Dashboard Informasi Sistem Penilaian Kinerja Pegawai Pada SDM di PT PLN Disjaya Area Cikokol," STMIK Raharja.

[8] "Yii The Best Framework PHP." [Online]. Available:

https://www.yiiframework.com/wiki/64/performa nce-a-guide-for-best-practice. [Accessed: 29-Jun2013]. 